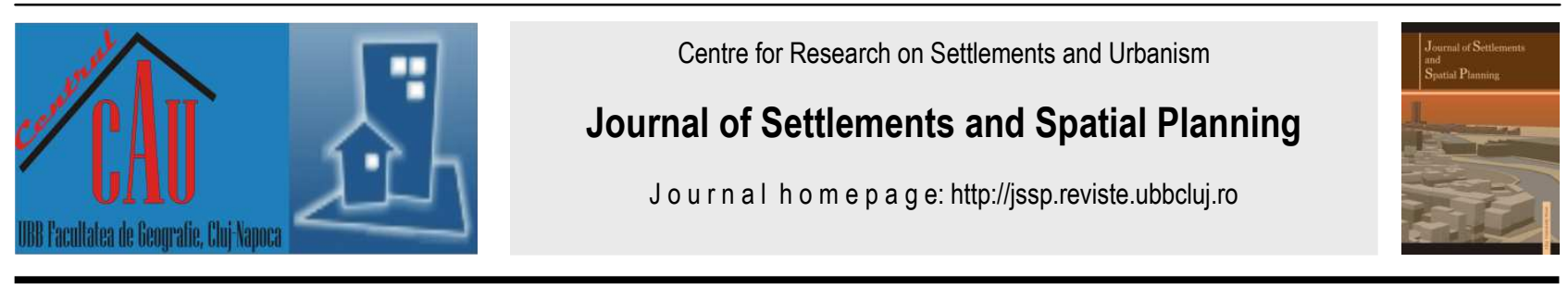

\title{
How Green are Romania’s Cities? A Quarter - Century of Green Area Policy
}

\author{
Bogdan-Nicolae PĂCURAR ${ }^{1}$ \\ ${ }^{1}$ Babeș-Bolyai University, Faculty of Geography, Centre for Research on Settlements and Urbanism, Cluj-Napoca, ROMANIA \\ E-mail: pacurarbogdan@ymail.com \\ DOI: 10.24193/JSSP.2017.1.06 \\ https://doi.org/10.24193/JSSP.2017.1.06
}

K e y w o r d s: green areas, urban, county capital city, policy, planning

\begin{abstract}
A B S T R A C T
Green areas are one of the most essential - but more often than not overlooked by planners, officials, and local governments functional parts of a city. This paper examines the evolution of such zones in 42 of the most important urban areas of Romania (the county capital cities) focusing on two years, 1993 and 2015. Furthermore, the paper links the evolution of green area developments to different legislative policies and planning practices that emerged after the fall of communism and the emergence of capitalism in this part of Europe. We conclude that the apparent expansion of green areas masks an unfortunate and somewhat dangerous situation, as a quarter of a century of territorial, regional, and local planning has failed to create not only good public green areas, but also enough square meters compared to built areas. Solutions can be found in improving the existing legislation and implementing new, more steadfast urban development schemes that put green areas at their very core.
\end{abstract}

\section{INTRODUCTION}

Cities, on a highly basic level, comprise of functional areas, such as: residential areas, industrial areas, transport areas, service areas, green areas etc. Even though they are often mentioned at the end of most enumerations, case in point, green areas and parks in particular are crucial for the proper growth and development of any city on the planet. However, the intention of this paper is not to present the merits of such spaces but rather to focus on how these urban open spaces have evolved in time. Our analysis will be limited to the period between 1993 and 2015 and will use Romania as case study.

More specifically, the paper will examine how urban planning and legislative policies have influenced the evolution of green areas, essentially what happened after the collapse of the planned economy, the socialist regime and the top-down planning practice and with the emergence of a more aggressive urban development and a market real estate economy. The analysis will include Bucharest (Romania's capital city) and the 41 county seats.

\section{THEORY AND METHODOLOGY}

With urban population exceeding 50\% of the world population and expected to increase to $66 \%$ by 2050, the quantity and quality of green spaces in urban areas have become key elements for sustaining the quality of human life in urban areas. Thus, the study and research of green areas and their role in the well-being of cities and its citizens has become not only of chief interest for scientists and urban theoreticians, but also urgent for local authorities and communities.

Reviewing the more recent scientific literature on the matter, one can observe two main research streams when it comes to the study of green areas: 1 . the influence of such spaces on different aspects of urban life and 2. the territorial dynamics of green areas.

The former path includes, for instance, the study conducted by Morancho (2003) who found a 
definitive link between housing processes and urban green areas by making several hundred observations in the city of Castellon, Spain [1]. In short, Morancho observed an inverse relationship between the selling price of the dwelling and its distance from a green urban area. The same year, Chiesura (2003) wrote about the emotional importance of parks in the urban setting, with a case study on Vondelpark, in Amsterdam, The Netherlands [2]. A review by Lee and Maheswaran (2010) concluded that a causal relationship between green areas and health is not supported by evidence and that such claims have previously been based on weak studies [3]. Four years later, the social and equality issues of green areas in the United States and China were tackled by Wolch, Newell and Byrne (2014), concluding that decision makers must focus on urban green space strategies that protect social as well as ecological sustainability [4]. Hodson and Sander (2017) showed that there is substantial evidence to support the idea that urban nature (green areas and spaces) is related to academic success [5].

The latter path, focusing on the territorial changes of urban green areas in concurrence and influenced by urban growth as a whole, encompasses a diverse roster of studies, centering on small cities as well as on large metropolises from across the globe. Kafafy (2010) used the capital city of Egypt, Cairo, as a case study for the research of the historical and territorial dynamics of urban green space in arid cities [6]. Zhou and Wang (2011) discussed the green spaces in Kunming, China, and their extraordinary changes within the 1992-2009 time frame [7], while Byomkesh, T., Nakagoshi, N., Dewan, A. M. (2011) explored the dynamics of green space in Greater Dhaka, Bangladesh, in the face of explosive urbanization [8]. Similarly, Kabisch and Haase (2012) studied the green spaces of major European cities between 1990 and 2006, noticing an increase in urban green spaces in Western and Southern Europe, and a decline in Eastern European urban cores along with a strong population decrease [9]. Both reports presented a picture defined by an increase in the size of residential areas at the expense of urban green spaces. Another study on European urban areas, this time conducted by Fuller and Gaston (2009), states that green space coverage actually increases more rapidly than city area, yet declines only slightly as human population density increases [10]. Thus, green space provision within a city is primarily related to city area rather than the number of inhabitants that it serves. The European Environmental Agency (EEA) published a map of green urban areas in several core cities of the European Union 27 (2015), and the picture did not look good, as most cities registered values between 0-20 percent [11]. Across the Pond, Sperandelli, Dupas and Dias Pons (2013) showed in their study on the metropolitan fringe of Sao Paolo, Brazil, that the little increase in green spaces that took place in the last few decades is actually the result of growth upon the remaining forests in periurban regions and the lack of green spaces and the excess of vacant land are difficulties faced by most Brazilian cities [12]. In between the two directions stands Astell-Burt et al.'s (2014) study on how lack of green space is linked to social inequalities in Australia's major urban areas. The study argues that inequitable distribution of parks and other 'green spaces' could exacerbate health inequalities if people on lower incomes, who are already at greater risk of preventable diseases, have poorer access [13]. In 2017, Anguluri and fellow researcher Narayanan studied the concepts of per capita urban green cover, green index for smart city planning and urban green infrastructure (UGI) and verified said concepts by using the City of Gulbarga, India, as a case study. It seems that the relationship between urban impervious surface and the vegetative surface is an important determinant of ecosystem process and the green cover studied in proportion with urban built environment can give better results, as asserted also by Pauleit and Breuste in 2011 [14], [15].

Romanian research on green areas is somewhat sporadic. Among the few studies on urban green areas, the work by Chiriac, Humă and Stanciu, (2009) bemoaned the general decrease of green areas in cities during the last decades and gave some generic solutions for this urban problem [16]. Others such as Morar et al. (2014) compared the parameter of green space per capita currently required by Romanian legislation to accessible green space per capita and found that only a quarter of the Romanian urban population benefits from proper access [17]. Luca et al. (2015) took a less sophisticated approach and looked into the evolution of such spaces in two major cities in Romania, after 1990, evaluating the gaps between the designed and existing situation in Romania's cities in relation to green areas, the introduction of urban green structure terminology in urban planning and strategic documents, and the need for a sustainable management of green structure in Romania [18].

The number of publications on green space have increased considerably since 2000 according to Taylor and Hochuli (2017), who reviewed multiple papers on the subject and ascertained that most publications fail to define what is meant by the term "green space", choosing to describe it either as nature or as urban vegetation. They continued by expressing the need for a definition that is both qualitative and quantitative in nature [19]. For this current scientific effort however, national Romanian law will be employed as it is the only one who sets the guidelines that govern green space management in Romania, one of the paper's main foci. Therefore, no outside definition will be employed but the one found in Law 24/2007 - "The green space law", which states that green areas consist of [20]: 
- public green areas with unlimited access: parks, gardens, green squares, planted strips;

- specialized public green areas: botanical and zoological gardens, open air museums, expo parks, green areas for such facilities as day care centers, kindergartens, schools, healthcare facilities, public institutions, religious centers, cemeteries, green areas ancillary to performance sport facilities;

- green areas for recreation purposes;

- green areas for lakes and waterway protection;

- protection corridors for infrastructure;

- recreation forests.

A similar definition/classification of green areas is used, for analysis purposes, by the National Statistics Institute of Romania and comprises those tracts of land arranged as parks, green squares, public gardens, as well as green areas of sport facilities within the built perimeter of cities and towns. However, it does not include greenhouses, plant nurseries, vegetable gardens, cemeteries, agricultural land, lakes, etc. [21]. This latter classification will be the one used in this paper since it is the only one which also provides hard statistical data for such spaces.

Government's decree 114/2007 for the modification and supplementation of Ordinance 195/2005 regarding environmental protection is only a couple of pages long, but contains one passage of law that sets the threshold for the minimum surface area of green space in human settlements [22]. As a side note, the idea behind this piece of legislation was that it took into account the degradation of urban green spaces in Romania caused by the development of economic and social activities, and tried to improve environmental factors and quality of life through the increase of green areas in settlements, their protection and sustainable management, as well as the increase in living standards. Furthermore, it acknowledged that the lack of an immediate regulation may lead to the inability to conduct proper environmental management in rural and urban areas, while the lack of strategic planning in this domain may result in severe health problems and low quality of life for the general population. In short, it recognized the gravity of the situation and proposed a solution.

The paragraph involving the minimal standard for green spaces contained by the decree reads as follows: Local authorities have the obligation to ensure at least 20 square meters of green space in built areas/inhabitant by $31^{\text {st }}$ December 2010, and at least 26 square meters/inhabitant by 31st December 2013. There are several conclusions that can be drawn from it:

- until 2007, the year of Romania's accession to the European Union, there have not been any rules setting the minimal amount of green area in Romania; as a result, there was a sense of urgency (as already mentioned) and institutional pressure mounted for Romania, the newest member of the $\mathrm{EU}$ at that time;
- Romanian authorities, in accordance to World Health Organization (WHO) and European Union (EU) norms, measure green space in relation to the number of inhabitants (population size) of each settlement [18];

- last but not least, Romanian law does not measure green space in relation to a city's or town's surface area, which would have added a more realistic take on the issue.

Taking all this into consideration, the paper at hand will map the green areas of Romania's county capitals ( 41 in total) and the Municipality of Bucharest in relation to the following indicators: population size (square meters of green space/capita) and city built up area (percentage \%), at two different temporal moments: 1993, the first year in which green areas where registered by the National Institute of Statistics, and 2015, when the last set of data was recorded [23]. These two years are enough to help the reader visualize what transpired after 1989 (the year the communist regime fell), since the purpose is not a monotone step by step, year by year evolution of urban green space.

The mapping process will be done with the help of Quantum GIS Desktop 2.2.0., resulting in two sets of comparative maps: 1. square meters of green space/inhabitant in 1993 and 2015, and 2. percentage of green areas out of city built up area in 1993 and 2015. This will give the reader a better view of the transformation experienced by urban green spaces and by cities in almost a quarter of a century of free real estate market and laissez-faire style territorial planning. It is extremely difficult to compare the situation of green areas in Romania or, to be more specific, what is defined as green area in Romanian legislation to other European Union (EU) member states or European countries, as the definitions do not match. Therefore, we focused solely on Romanian cities, in particular on county capitals and the city of Bucharest, where the pressure on urban green areas is the highest.

\section{RESULTS AND DISCUSSION}

When comparing the 1993 and 2015 surface area occupied by green spaces in the largest cities of each Romanian county to population size (the number of inhabitants in 1993 and 2015), the map in figure 1 presents a positive situation, a 'green evolution'.

Most county capitals increased their green spaces, with only 10 cities losing green space (Râmnicu Vâlcea, with the most significant decrease, from 30.52 $\mathrm{m}^{2}$ /capita to $16.77 \mathrm{~m}^{2}$ /capita, followed by Arad, Brașov, Constanța, Târgu Jiu, Drobeta Turnu Severin, Slatina, Sibiu, and Romania' capital, Bucharest). The greatest increases in green space were registered by less populous cities (Baia Mare, from $21.53 \mathrm{~m}^{2} /$ capita to an astounding $117.69 \mathrm{~m}^{2} /$ capita, Buftea, Miercurea Ciuc, and Bistrița). 
By contrast, if one should compare the percentage of green urban space to the built up area (termed 'teritoriu intravilan' in Romanian and Romanian planning law) of every county capital and the Municipality of Bucharest (ratio of green area in square meters to built-up area in square meters), the situation changes dramatically. But before moving on, the meaning of built up area must be addressed for a better

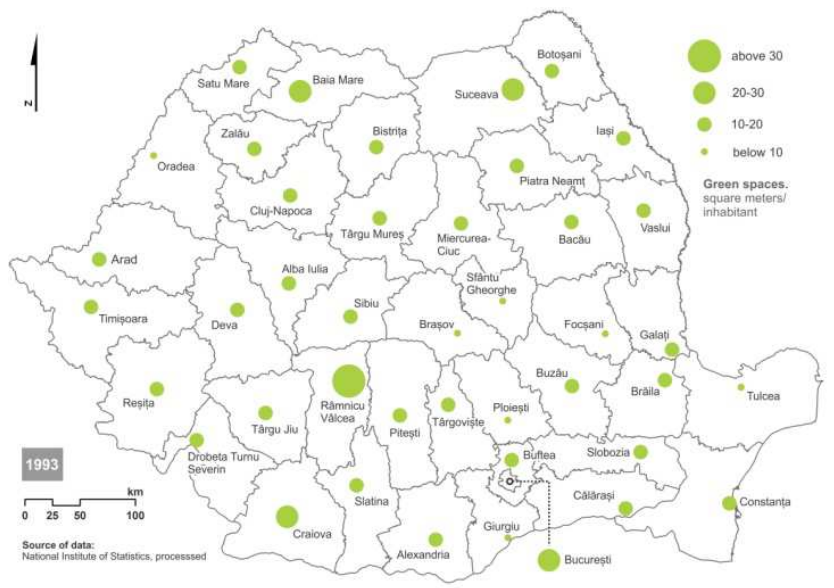

grasp of the idea. According to Law 350/2001 regarding territorial planning and urbanism, the built up area (intravilan) is the sum of all built or developed surfaces of the settlements that comprise the basic territorial unit (city, town or commune - LAU 2 level entities), demarcated by an approved general urban plan and where construction and further development are allowed [24].

Fig. 1. Square meters of urban green space/capita in Romania (county capitals and Bucharest). 1993 and 2015 comparison.

As one can see in figure 2, the vast majority of urban centers in Romania had lower percentages of green space in relation to their built areas in 2015 than in 1993, only 9 of them increasing this value in the given time frame (Bistrița, Reșița, Călărași, Craiova, Giurgiu, Miercurea Ciuc, Baia Mare, Ploieşti, and Satu Mare). These cities are not only modest in terms of population size, but also small in surface area, and have experienced particularly slow horizontal (territorial)

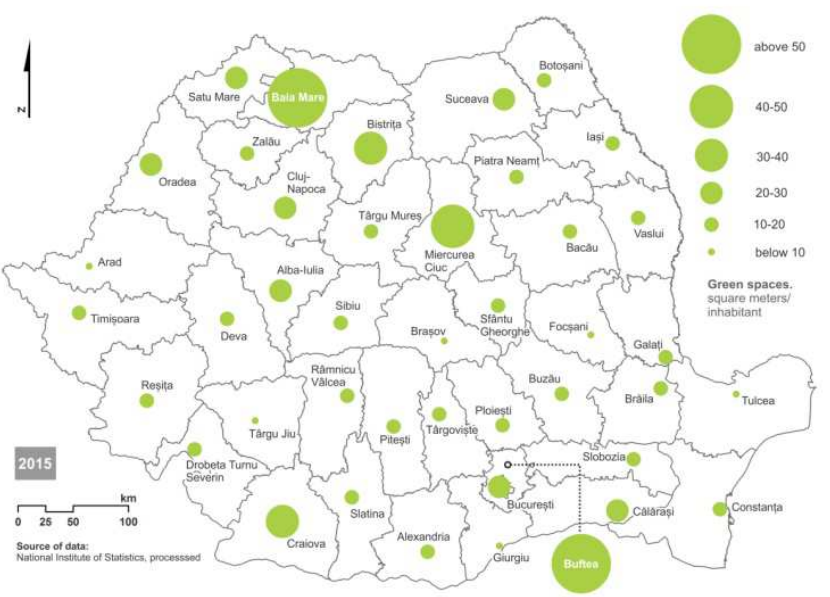

expansion or sprawl. However, this rule does not apply to Râmnicu Vâlcea apparently, a lower tier town with a population of less than 100,000 inhabitants, which had the largest recorded decrease, from 32.58\% in 1993 to 4.11\% in 2015. The set is completed by cities such as Bucharest, Alba Iulia, Braşov, Târgu Jiu, Cluj-Napoca, etc, while most urban areas experienced only negligible decline of said ratio.
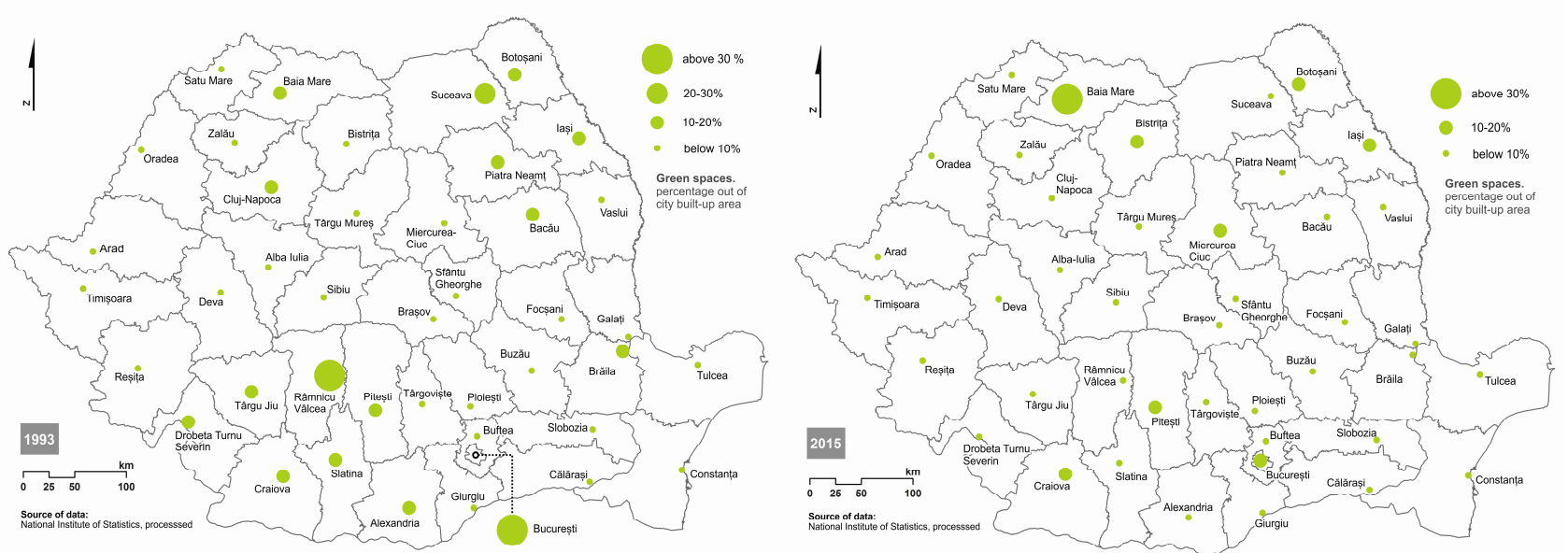

Fig. 2. Percentage of urban green space out of built-up area in Romania (county capitals and Bucharest). 1993 and 2015 comparison.

Putting the above presented two figures side by side, it is utterly clear that even though the surface areas covered by green spaces kept pace with the demographic evolution of Romanian cities, they fell behind in terms of expansion of built up areas. As cities grew and grew, taking up more and more rural-urban fringe land, the land covered by parks, gardens and generally green space remained at the same level as in 1993 or even decreased. With very few exceptions, most cities became "green space deserts", an oxymoron that perfectly encapsulates the lack of not only green areas, but also of functional open/public places. Residential 
development had become the priority in many communities, local authorities and developers completely ignoring the need for green space. Such a thing became an afterthought, well behind housing, retail, parking spaces or roads. For instance, in ClujNapoca, in 25 years, only a single major green area (Iulius Park - roughly 3 hectares [25]) was created from scratch, largely thanks to private initiative, the local and county government having limited contributions.

In this article's view, to regulate green space in relation to population size or green space/ capita, especially at national level, is misleading and even erroneous due to the fact that there is a tendency of Romanian cities to extend their territory and not to densify. The number of inhabitants of county capitals have generally decreased (few cities saw a rise in population from 1993 to 2015), but their territorial footprint has extended considerably. As stated by Kasanko et al. (2006), the structure of European cities has become less compact, leading either to urban sprawl or to an urban dispersion, and the cities of Romania have followed the same trend as well in the last quarter of century [26].

This implies that every inhabitant benefits from green space disproportionately. The current statistical data solely acknowledges population, ignoring built area expansion, which is almost entirely disproportionate to population evolution. Romanian cities expanded faster in size than in population, leading to 'sprawl'. If one should sum up the population size of each county capital, in 1993 and 2015, and compare the two results $(8,231,471$ and $8,211,600$ inhabitants respectively), one would observe a decrease in population of roughly $0.02 \%$. However, in terms of built up area, the numbers tell a different story, as between 1993 and 2015, the surface area of all county capital cities, including the City of Bucharest, surged by a staggering $41 \%$, from 108,896 hectare to 183,669 hectares. In short, more land for fewer people.

It should no longer matter how much urban green space per each people living in cities there is, but rather how much green space there is compared to each city's actual mark on the land itself. When an urban area expands considerably, but lags behind, even slightly, in population and green growth, it creates imbalances and inequality in providing its people the green spaces they need. Therefore, an overhaul of how statisticians, urban geographers, city and national governments view cities is badly needed, meaning that the green space/capita indicator must be gradually abandoned for a more comprehensive and better benchmark, one that will acknowledge the territorial component as well as the populace.

In short, green area or green space/built-up area creates an image that is closer to the reality on the ground than the current green area or green space/capita.
With all the above in mind, we would like to make several proposals for alleviating the existing problems regarding the green areas of Romanian cities: applying the green space/built up area indicator and continuously improving it, developing better green area databases, creating better and more urban green and applying eminent domain in law and on the ground. This last concept, also known as expropriation or compulsory purchase, is defined as the power of a state or government to take (buy) private property and put it for public usage. In Romanian law, such notion is governed by two legislative deeds, the first one (in chronological order) being Law 33/1994 regarding eminent domain [27], while the second came more than 15 years later, Law nr. 255/2010 for national, county and local objectives [28]. Both laws state several objectives for which eminent domain can be applied, such as road infrastructure, railroads or utilities, but do not include any reference towards green areas, green space, urban forestry etc. The inclusion of such concepts in the list of public utility works might give more legislative influence for such issues and might embolden national, regional or local governments to acquire land by purchasing it from private hands and turn it into new urban green infrastructure where such areas are vital or necessary. Withal, private developers and land owners should be helped to understand the value and necessity of not only nonpublic green areas, but also of public and semipublic green infrastructure, and that in urban planning (green planning) the public and the private realms matter the same. More publicprivate development should be encouraged, especially ones that will lead to the creation of a greater and more cohesive park network.

Another proposal, this time much more discreet but still crucial to the development of urban green areas, would be to exclude or at least modify point 6 of article 18 of Law 24/2007 (already mentioned above) which states that one can change the zoning of an area from green area to other designations, as long as it complies with the public utility objectives mentioned in Law 33/1994, which includes, among others, roads and highways, This legislative article should be altered to make it impossible to be used by national or local governments to indiscriminately and irreversibly destroy existing urban green areas.

\section{CONCLUSIONS}

Despite being only partially monographic, the article presented the situation of urban green areas at two moments in Romania's history. However, it went beyond that level and proposed a new way of quantifying green areas in cities, with useful implications for territorial and urban planning law and, thus, for the actual development and improvement of the urban environment. The study was not meant to 
present a basic evolution of green areas in Romania's cities, but rather to emphasize that the current indicator is flawed.

Based on our research, we contend that the situation of green spaces in Bucharest and in the 41 county seats in Romania is worse than the statistics based on the indicator currently used may indicate., both at ground level and at policy level. There is a need for a revision of green space indicators found in the existing legislation, which can be translated afterwards in the planning process proper, thus significantly contributing to a superior urban environment and better living conditions. Since urban green areas are a public good, city officials must not remain idle and must foremost work to improve the existing legislation and to implement it into actual urban planning practices.

\section{ACKNOWLEDGEMENTS}

The author wishes to thank for the support provided by the Department of Territorial Planning of Cluj County Council and by the Centre for Urbanism and Settlements Research, Faculty of Geography, Babeș-Bolyai University Cluj-Napoca.

\section{REFERENCES}

[1] Morancho, A. B. (2003), A hedonic valuation of urban green areas, Landscape and Urban Planning, 66(1), pp. 35-41, United States.

[2] Chiesura, A. (2003), The role of parks for the sustainable city, Landscape and Urban Planning 68, pp. 129-138, United States.

[3] Lee, A. C., Maheswaran, R. (2011), The health benefits of urban green spaces: $A$ review of the evidence, Journal of Public Health 33(2), pp. 212-222, United States.

[4] Wolch, J. R., Byrne, J., Newell, J. P. (2014), Urban green space, public health, and environmental justice: the challenge of making cities 'just green enough', Landscape and Urban Planning 125, pp. 234244, United States.

[5] Hodson, C. B., Sander, H. A. (2017), Green urban landscape and school-level academic performance, Landscape and Urban Planning, Vol. 160, pp. 16-27.

[6] Kafafy, N. A. A. (2010), The dynamics of urban green space in an arid city: the case of Cairo, Egypt, ProQuest LLC, United States.

[7] Zhou, X., Wang, Y. C. (2011), Spatial temporal dynamics of urban green space in response to rapid urbanization and greening policies, Landscape and Urban Planning 100(3), pp. 268-277, United States.

[8] Byomkesh, T., Nakagoshi, N., Dewan, A. M. (2011), Urbanization and green spaces dynamics in
Greater Dhaka, Bangladesh, Landscape and Ecological Engineering, vol. 8, issue 1, pp. 45-58.

[9] Kabisch, N., Haase, D. (2013), Green spaces of European cities revisited 1990-2006, Landscape and Urban Planning 110, pp. 113-122, United States.

[10] Fuller, R. A., Gaston, K. J. (2009), The scaling of green space coverage in European cities, Biology Letters, Volume 5, Issue 3, United States.

[11] *** (2015), http://www.eea.europa.eu/data-andmaps/figures/percentage-of-green-urban-areas-1, Last accessed: $2^{\text {nd }}$ December 2016.

[12] Sperandelli, D., Dupas, F., Dias Pons, N. (2013), Dynamics of urban sprawl, vacant land, and green spaces in the metropolitan fringe of Sao Paolo, Brazil, Journal of Urban Planning and Development, Vol. 139, Issue 4, pp. 274-279, United States.

[13] Astell-Burt, T. et al. (2014), Do low-income neighbourhoods have the least green space? A crosssectional study of Australia's most populous cities, BMC Public Health, Vol. 14.

[14] Anguluri, R., Narayanan, P. (2017), Role of green space in urban planning. Outlook towards smart cities, Urban Forestry and Urban Greening, in press, accepted manuscript.

[15] Pauleit, S., R., Breuste, J. H. (2011), Land-Use and Surface-Cover as Urban Ecological Indicators, in Urban Ecology, Oxford University Press, United Kingdom.

[16] Taylor, L., Hochuli, D. F. (2017), Defining greenspace. Multiple uses across multiple disciplines, Landscape and Urban Planning, Vol. 158, pp. 25-38.

[17] Chiriac, D., Humă, C., Stanciu, M. (2009), Spațiile verzi - o problemă a urbanizării actuale [Green spaces - a problem of current urbanization], Calitatea Vieții, XX, nr. 3-4, pp. 249-270.

[18] Morar, T. et al. (2014), Assessing Pedestrian Accesibility to Green Space using GIS, Transylvanian Review of Administrative Studies, no. 42, pp. 116-139.

[19] Luca, O. et al. (2015), Green structure in Romania: the true story, in Sustainable Development and Planning VII, WIT Press, United Kingdom.

[20]*** Law 24/2007 regarding the regulation and administration of green spaces in the settlement built up areas, Romanian Parliament.

[21] *** Government's Emergency Ordinance 114/2007 for the modification and supplementation of Ordinance 195/2005 regarding environmental protection, Government of Romania.

[22] *** (2016), Supporting the Implementation of Green Infrastructure, Final Report, European Commission, available at: http://ec.europa.eu/ environment/nature/ecosystems/docs/green_infrastru ctures/GI\%20Final\%2oReport.pdf, last accessed: 2nd December 2016.

[23] ** TEMPO-online, National Institute of Statistics, Romania, Last accessed: November, 14th, 2016.

[24] *** Law 350/2001 regarding territorial planning and urbanism, Romanian Parliament. 
[25] *** https://cluj.com/locatii/iulius-parc/, last accessed: 11th December 2016.

[26] Kasanko et al. (2006), Are European cities becoming dispersed? A comparative analysis of 15 European urban areas, Landscape and Urban Planning, Vol. 77, issue 1-2, pp. 111-130
[27] ** Law nr. 33/1994 regarding eminent domain, Parliament of Romania.

[28] *** Law nr. 255/2010 regarding eminent domain for national, county and local objectives, Parliament of Romania. 